\title{
The Role of Local Authorities in Addressing Human Trafficking
}

\section{Commonwealth Journal of Local Governance \\ Issue 3: May 2009}

http://epress.lib.uts.edu.au/ojs/index.php/cjlg

\section{Kathryn Rossiter}

Director of Development and Operations, Society of Local Authority Chief Executives and Senior Managers (SOLACE)

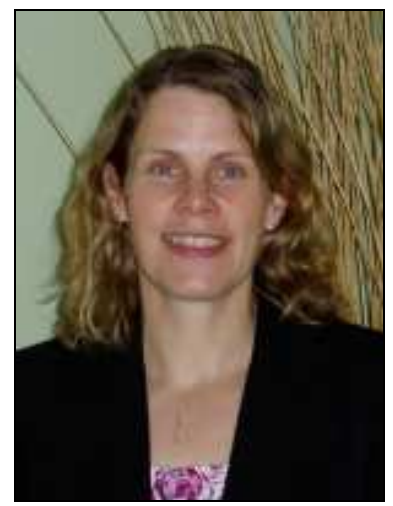

\section{Jo Benfield}

International Consultant to SOLACE

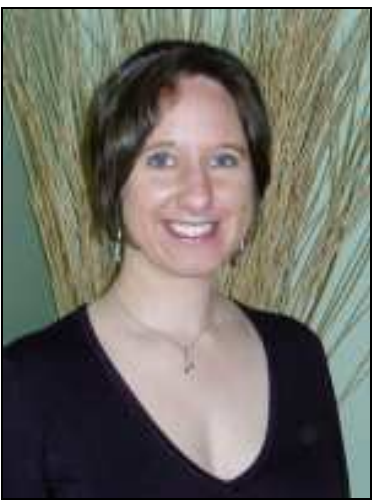

Key words: Human trafficking, role of authorities, victim identification, prostitution, slavery, illegal labour, victim support, prevention

\section{Introduction}

Worldwide, it is estimated that nearly 4 million people fall victim to people traffickers every year. Trafficking is carried out mainly by Organised Criminal Networks and the victims are forced into prostitution, illegal labour, domestic slavery and petty crime. 
On 1 April 2009, the United Kingdom signed up to the Council of Europe Convention on Action against Trafficking in Human Beings. ${ }^{1}$ The Convention, which has to date been ratified by 20 European countries, is legally binding and aims to promote and protect the rights of victims who have been tricked or forced into leaving their homes, moved to another country, or within their own country, and then exploited. Whilst it is national governments who are signatories to the Council of Europe Convention, local authorities have a key role to play in its successful implementation.

The UK Society of Local Authority Chief Executives and Senior Managers (SOLACE) has undertaken a year-long project to identify how local authorities can improve their response to the crime of human trafficking. A full report of the findings of this research can be found on the SOLACE website. ${ }^{2}$ SOLACE has identified five core competencies (refer to Appendix 1) that local authorities need to develop if they are to address the challenges of human trafficking:

(i) victim identification (refer to Appendix 2)

(ii) victim support

(iii) assistance with repatriation of victims

(iv) prevention of human trafficking

(v) working in partnership.

This article explores these five competences and concludes by drawing some key lessons for local authorities interested in developing anti-trafficking strategies.

\section{Victim Identification}

The early identification of victims is key to ending the abuse that they suffer and to providing the assistance necessary to begin their rehabilitation. This requires close collaboration between different actors in the victim identification process. Local authority staff work alongside police officers, immigration officials and others to identify potential victims. Frontline staff need to be equipped with effective skills and tools in order to observe signs of trafficking and to know how to act upon these. They will also need training in undertaking specific tasks, such as age assessments of young victims.

\footnotetext{
${ }^{1}$ A copy of the Convention can be found on: 〈http://conventions.coe.int/Treaty/EN/Treaties/Html/197.htm>

${ }^{2}$ The SOLACE report on The Role of Local Authorities in Addressing Human Trafficking can be downloaded from <http://www.solace.org.uk/news_downloads.htm>
} 
Victims identified as being children should be provided with representation by a guardian or authority that will act within their best interests; the authorities should try to establish the victim's identity and all efforts should be made to locate the victim's family. Finally, local authorities should be aware of the phenomenon of internal trafficking whereby adults and children are trafficked within a country; in the UK this is thought to be primarily for the purpose of sexual exploitation.

\section{Victim Support}

Once identified, victims of human trafficking need to be supported in their physical, psychological and social recovery. At a minimum, victims should be provided with appropriate and secure accommodation, psychological and material assistance, access to emergency medical treatment, information on rights, access to an interpreter/translation and legal advice, and access to education for children.

It is the role of victim support which is at the core of the local authority response to human trafficking. Local government needs to be able to provide easily accessible advice to potential victims, adopting a proactive approach to seeking them out in their working or home environment, where possible. Service provision needs to be carried out in a coordinated manner with other agencies, particularly with health providers, local nongovernment organisations, the police and immigration authorities.

Trafficked children are of particular concern to local authorities; studies in the UK show that up to half of this group go missing from local authority care (Kapoor 2007, pp. 4849), with comparable figures in many other European countries. Councils therefore need to tighten provision for secure accommodation and provide training carers on the specific dangers that a trafficked child faces from their traffickers.

Many victims of trafficking will face significant linguistic barriers to accessing services, and councils should be aware of the most effective measures to take in order to address these. The provision of support to victims cannot be limited to physical services such as accommodation and schooling; the victim's psychological needs must be addressed from the initial point of contact between the victim and the local authority. 
To ensure that victims do not fall back into the hands of their traffickers, it may be necessary to equip them with new skills to support themselves financially and to rebuild their confidence. Local government will need to work in partnership with local voluntary organisations and training providers to meet these needs. When providing services to victims, local authorities need to ensure that the victims are at all times safe from their traffickers, and all data about the victim should be treated with the utmost confidentiality. Staff must develop a real understanding of each individual victim's needs and be able to respond to these accordingly, in partnership with other actors in the local area.

\section{Assistance with Repatriation of Victims}

It may be appropriate in some cases for victims of trafficking to return to their country of origin. The repatriation of victims is a complex legal process, involving the legal systems of the countries of origin and destination, and the rights, dignity and safety of victims must always be protected. Whilst local authorities are unlikely to have a defined role in the repatriation process, they will probably have a duty of care towards victims living in their area. The local authority will therefore need to be assured that a victim's safety and security has been taken into account if they are to be returned to their home country; this may involve working closely with the local authorities in the victim's country of origin. The local authority may also assist in preparing the victim for return, working closely with organisations such as the International Organisation for Migration to ensure that the victim is safely repatriated.

\section{Prevention of Human Trafficking}

Local authorities do not immediately come to mind as key actors in the prevention of human trafficking. However, there are a number of aspects of prevention in which they do have an important role to play. These include ensuring that local communities are informed about the phenomenon of trafficking and that citizens can begin to identify potential victims. Local authorities can also assist the police in the identification of traffickers, using evidence gathered through contact with the victim. Finally local authorities can implement anti-trafficking measures designed to reduce demand for victims of trafficking, for instance, among men who use sexual services. A useful resource for local authorities interested in raising awareness of human trafficking issues is the Blue Blindfold campaign (United Kingdom Human Trafficking Centre 2007). Instigated by the UK Human Trafficking Centre, this campaign is being rolled out on an 
international level to highlight the signs of trafficking that citizens may come across in their local communities.

\section{Working in Partnership}

Local authorities must work closely with other actors if they are to successfully address the challenges of human trafficking. At a local level, cooperation between councils, the police, primary care trusts and voluntary bodies is a pre-requisite for success. All agencies involved in the identification and care of the victim should be clear about their respective roles and responsibilities, using formal cooperative structures and protocols where appropriate. Local government will also need to work closely with national bodies such as the immigration authorities.

\section{Conclusions}

One of the greatest challenges in meeting the needs of victims of trafficking is a lack of knowledge and understanding about the crime of trafficking and the needs of the victims. As local government plays a key role in addressing victims' needs, it is imperative that politicians and staff at all levels have a comprehensive insight into the issues and problems.

Protecting the rights of the victim should be the first priority of all anti-trafficking measures. A human-rights based approach must be adopted, which puts the needs of the victim above the need to catch the traffickers. This victim-centred approach should be at the heart of all local government strategies on trafficking and should be the central foundation upon which local government services for victims are delivered.

All local government strategies to address the challenges of human trafficking should build upon existing local procedures. There is no need to re-invent the wheel: local authorities will, for example, probably have procedures in place for taking care of children who are at risk and these can form the core of a strategy for helping child victims of trafficking. The needs of victims can also be addressed through local authority strategies to tackle violence against women and prostitution, as well as through work with migrant communities. 
In developing trafficking strategies, local authorities should bear in mind the full range of human trafficking crimes. Whilst most people think of trafficking in terms of victims who are forced into prostitution, local authorities may also encounter victims who have been trafficked for other purposes, for example forced labour and petty crime such as pick- pocketing, shoplifting and begging. It should also be remembered that it is not only women and children who are trafficked. Men also become victims, particularly in the field of forced labour. Finally, any definition of trafficking must take into account the phenomenon of internal trafficking, whereby victims are trafficked within a country, rather than from abroad.

Combating trafficking and assisting victims requires a multi-disciplinary and cooperative approach, involving a wide range of stakeholders. Local authorities have an important role to play, but will not be successful if they try to operate in a vacuum. Local authorities should be clear about the respective competences and responsibilities that they and the other actors have. This should help to ensure a seamless provision of services to the victim. Local authorities can perform a mapping exercise to ensure that they have a proper overview of the actors in their local area and in the national context who are involved in the identification and provision of support to victims. In addition to the police, health providers, and local voluntary organisations, it is important for local authorities to work closely with embassies of the countries of origin of victims, the International Organisation for Migration and the immigration authorities.

Finally, it is important to remember that trafficking is a crime that transcends borders. Organised Criminal Networks move victims from one country to another, and local and national authorities will not be successful in combating the crime unless they also begin to think internationally. The Council of Europe Convention on Action against Trafficking in Human Beings provides a common set of European standards for identifying and assisting victims and for successfully pursuing traffickers that can prove useful across the world. However, there is still a need for a truly international approach to addressing the challenges of human trafficking; international tools need to be developed, such as a victim database that will help to identify victims who have already been trafficked to another country, and an international directory of services for victims. Much more still needs to be done to ensure that, at the local, national and international 
levels, victims are offered the highest level of protection and that all actors work together to combat this heinous crime.

\section{References:}

Council of Europe 2005, Council of Europe Convention on Action against Trafficking in Human Beings, Council Of Europe, accessed 04 May 2009, $\langle$ http://conventions.coe.int/Treaty/EN/Treaties/Html/197.htm>.

SOLACE 2009, The role of local authorities in addressing human trafficking, SOLACE, accessed 04 May 2009, 〈http://www.solace.org.uk/news downloads.htm>.

Kapoor, Aarti 2007, A Scoping Project on Child Trafficking in the UK, Child Exploitation and Online Protection (CEOP) Centre, accessed 04 May 2009, 〈http://www.homeoffice.gov.uk/documents/ceop-child-traffick-report-0607?view=Binary〉. United Kingdom Human Trafficking Centre 2007, Sheffield, UK, accessed 04 May 2009, <http://www.blueblindfold.co.uk>. 


\section{APPENDIX 1:}

\section{THE SOLACE COMPETENCE FRAMEWORK}

SOLACE has developed the following framework to assist local authorities in assessing their performance in identifying and assisting victims of human trafficking at a strategic level. It provides a set of core competences that local authorities need to develop in order to successfully address the problems of human trafficking.

\begin{tabular}{|c|c|}
\hline Competence & Evidence \\
\hline \multicolumn{2}{|l|}{ HT1 Victim Identification } \\
\hline $\begin{array}{l}\text { 1.1 Local Authority cooperates effectively } \\
\text { with all other actors involved in victim } \\
\text { identification, including police, immigration } \\
\text { services and national authorities }\end{array}$ & $\begin{array}{l}\text { Co-ordination mechanisms between } \\
\text { Local Authorities, national authorities, } \\
\text { police and immigration in place and } \\
\text { functioning effectively }\end{array}$ \\
\hline $\begin{array}{l}1.2 \text { Local Authorities are integrated into } \\
\text { formal processes for identifying victims }\end{array}$ & $\begin{array}{l}\text { Local Authorities understand and } \\
\text { effectively carry out their designated } \\
\text { roles within the National Referral } \\
\text { Mechanism }\end{array}$ \\
\hline $\begin{array}{l}\text { 1.3 Frontline staff have the skills and } \\
\text { knowledge necessary to proactively } \\
\text { identify potential victims of trafficking }\end{array}$ & $\begin{array}{l}\text { Training provided for frontline staff } \\
\text { (including environmental health officers, } \\
\text { health visitors, etc) in identification of } \\
\text { victims }\end{array}$ \\
\hline $\begin{array}{l}1.4 \text { Local Authority staff have the } \\
\text { necessary skills and training to be able to } \\
\text { carry out age assessments for potential } \\
\text { child victims of trafficking }\end{array}$ & $\begin{array}{l}\text { Suitable staff are identified and they feel } \\
\text { confident in undertaking age } \\
\text { assessments; victims suspected of being } \\
\text { minors are identified quickly and } \\
\text { provided with the relevant support }\end{array}$ \\
\hline $\begin{array}{l}1.5 \text { Local Authority understands the } \\
\text { phenomenon of internal trafficking and } \\
\text { implement procedures to identify potential } \\
\text { victims }\end{array}$ & $\begin{array}{l}\text { Local Authority staff dealing with } \\
\text { vulnerable UK nationals, particularly } \\
\text { minors, are trained in the identification of } \\
\text { victims }\end{array}$ \\
\hline \multicolumn{2}{|l|}{ HT2 Victim Support } \\
\hline $\begin{array}{l}2.1 \text { Local Authority provides easily } \\
\text { accessible advice to victims of trafficking }\end{array}$ & $\begin{array}{l}\text { Resource centres/support units for } \\
\text { victims are established and provide } \\
\text { access across sectors }\end{array}$ \\
\hline $\begin{array}{l}2.2 \text { Local Authority provides suitable, safe } \\
\text { and secure accommodation for victims }\end{array}$ & $\begin{array}{l}\text { Secure accommodation is provided for } \\
\text { child victims and is managed by trained } \\
\text { individuals }\end{array}$ \\
\hline $\begin{array}{l}2.3 \text { Local Authority and other service } \\
\text { providers supply joined-up, coordinated } \\
\text { services to the victim }\end{array}$ & $\begin{array}{l}\text { Victims can access all Local Authority } \\
\text { services via a single point of contact }\end{array}$ \\
\hline $\begin{array}{l}2.4 \text { Trafficked children receive impartial } \\
\text { and coordinated care, advice and services }\end{array}$ & $\begin{array}{l}\text { Child victims have coordinated care } \\
\text { plans across all service providers which } \\
\text { address their individual needs }\end{array}$ \\
\hline $\begin{array}{l}2.5 \text { Local Authority addresses linguistic } \\
\text { barriers to access to services }\end{array}$ & $\begin{array}{l}\text { Assistance provided in victim's own } \\
\text { language }\end{array}$ \\
\hline
\end{tabular}




\begin{tabular}{|c|c|}
\hline Competence & Evidence \\
\hline $\begin{array}{l}2.6 \text { Local Authority understands and } \\
\text { addresses psychological needs of victims }\end{array}$ & $\begin{array}{l}\text { Local Authority supports community } \\
\text { groups in providing psychosocial support } \\
\text { to all victims }\end{array}$ \\
\hline $\begin{array}{l}2.7 \text { Victims gain skills that will assist them } \\
\text { in integrating into their new societies }\end{array}$ & $\begin{array}{l}\text { Education and training opportunities } \\
\text { provided for victims of trafficking }\end{array}$ \\
\hline $\begin{array}{l}2.8 \text { Victims in Local Authority care are } \\
\text { adequately protected from their traffickers }\end{array}$ & $\begin{array}{l}\text { Child victims do not go missing from } \\
\text { Local Authority care and addresses are } \\
\text { confidential }\end{array}$ \\
\hline $\begin{array}{l}2.9 \text { Local Authority staff who come into } \\
\text { contact with victims understand their } \\
\text { specific needs and circumstances }\end{array}$ & $\begin{array}{l}\text { Training in care for victims of trafficking } \\
\text { provided to all Local Authority staff } \\
\text { involved in providing services to them }\end{array}$ \\
\hline \multicolumn{2}{|l|}{ HT3 Assistance with Repatriation of Victims } \\
\hline $\begin{array}{l}\text { 3.1 Local Authority assists in assuring } \\
\text { victim's safety and security on return to } \\
\text { their home country }\end{array}$ & $\begin{array}{l}\text { Local Authority cooperates with its } \\
\text { counterparts in victim's country of origin } \\
\text { to ensure ongoing support for victim after } \\
\text { repatriation }\end{array}$ \\
\hline $\begin{array}{l}3.2 \text { Local Authority assists in preparing the } \\
\text { victim for return }\end{array}$ & $\begin{array}{l}\text { One-to-one psychological support and } \\
\text { training are provided to victim to prepare } \\
\text { them for repatriation }\end{array}$ \\
\hline \multicolumn{2}{|l|}{ HT4 Prevention of Human Trafficking } \\
\hline $\begin{array}{l}4.1 \text { Local population informed about any } \\
\text { potential human trafficking issues within } \\
\text { their community }\end{array}$ & $\begin{array}{l}\text { Local Authority runs community } \\
\text { information and awareness campaigns }\end{array}$ \\
\hline $\begin{array}{l}4.2 \text { Local Authority plays a proactive role in } \\
\text { the identification of traffickers }\end{array}$ & $\begin{array}{l}\text { Local Authority has mechanisms in place } \\
\text { to cooperate with police in the } \\
\text { identification of traffickers }\end{array}$ \\
\hline $\begin{array}{l}4.3 \text { Local Authority works in partnership } \\
\text { with local community groups to implement } \\
\text { anti-trafficking measures }\end{array}$ & $\begin{array}{l}\text { Local Authority provides financial and } \\
\text { logistical support to NGOs involved in } \\
\text { prevention of trafficking }\end{array}$ \\
\hline \multicolumn{2}{|l|}{ HT5 Working in Partnership } \\
\hline $\begin{array}{l}\text { 5.1 Local Authority works in partnership } \\
\text { with other agencies at the local level }\end{array}$ & $\begin{array}{l}\text { Specific anti-trafficking cooperation } \\
\text { mechanisms exist at the local level }\end{array}$ \\
\hline $\begin{array}{l}5.2 \text { Local Authority works in partnership } \\
\text { with national authorities }\end{array}$ & $\begin{array}{l}\text { Regular discourse between Local } \\
\text { Authority and national ministry } \\
\text { responsible for trafficking issues }\end{array}$ \\
\hline $\begin{array}{l}\text { 5.3 Local Authority understands the } \\
\text { implications of the Council of Europe } \\
\text { Convention on Action Against Trafficking in } \\
\text { Human Beings }\end{array}$ & $\begin{array}{l}\text { Key Local Authority managers and staff } \\
\text { who deal with victims of trafficking are } \\
\text { aware of the Convention and understand } \\
\text { its relevance for their own roles }\end{array}$ \\
\hline
\end{tabular}




\section{APPENDIX 2:}

\section{LOCAL AUTHORITY VICTIM IDENTIFICATION AUDIT}

\begin{tabular}{|c|c|c|c|}
\hline \multicolumn{4}{|l|}{ Child Victims } \\
\hline $\begin{array}{l}\text { Where do we } \\
\text { look? }\end{array}$ & What do we look for? & $\begin{array}{l}\text { Who is likely to } \\
\text { be the first } \\
\text { point of } \\
\text { contact? }\end{array}$ & $\begin{array}{l}\text { How do we } \\
\text { ensure that we } \\
\text { are picking up } \\
\text { the signs? }\end{array}$ \\
\hline $\begin{array}{l}\text { Care homes } \\
\text { and foster } \\
\text { families }\end{array}$ & $\begin{array}{l}\text { Has a history of going missing } \\
\text { and of unexplained moves } \\
\text { Received unexplained phone } \\
\text { calls } \\
\text { Possesses money and goods } \\
\text { not accounted for } \\
\text { Adults loitering outside the } \\
\text { place of residence }\end{array}$ & $\begin{array}{l}\text { Foster carers } \\
\text { Children's } \\
\text { Services } \\
\text { LSCBs }\end{array}$ & $\begin{array}{l}\text { LSCB sub-group } \\
\text { on child } \\
\text { trafficking formed } \\
\text { Training provided } \\
\text { for foster carers } \\
\text { and social } \\
\text { workers on victim } \\
\text { identification }\end{array}$ \\
\hline $\begin{array}{l}\text { Private } \\
\text { homes }\end{array}$ & $\begin{array}{l}\text { Different children living in the } \\
\text { same home at different times } \\
\text { Child has limited freedom of } \\
\text { movement } \\
\text { Performs excessive } \\
\text { housework chores and rarely } \\
\text { leaves home } \\
\text { Child is malnourished } \\
\text { Has not been registered with } \\
\text { or attended a GPs practice } \\
\text { Has not been enrolled in a } \\
\text { school }\end{array}$ & $\begin{array}{l}\text { Children's } \\
\text { Services }\end{array}$ & $\begin{array}{l}\text { Social workers } \\
\text { trained in } \\
\text { identification of } \\
\text { trafficked children }\end{array}$ \\
\hline Schools & $\begin{array}{l}\text { Unexplained periods of } \\
\text { absence from school } \\
\text { Signs of physical/sexual } \\
\text { abuse }\end{array}$ & $\begin{array}{l}\text { Teachers } \\
\text { Children's } \\
\text { Services }\end{array}$ & $\begin{array}{l}\text { Training and } \\
\text { information } \\
\text { materials } \\
\text { provided for } \\
\text { teachers }\end{array}$ \\
\hline $\begin{array}{l}\text { Hospitals and } \\
\text { GPs surgery }\end{array}$ & $\begin{array}{l}\text { Shows signs of } \\
\text { physical/sexual abuse }\end{array}$ & $\begin{array}{l}\text { Children's } \\
\text { Services } \\
\text { A\& E staff and } \\
\text { GPs }\end{array}$ & $\begin{array}{l}\text { Protocol between } \\
\text { Children's } \\
\text { services and PCT } \\
\text { to ensure checks } \\
\text { against Child } \\
\text { Protection } \\
\text { Register are } \\
\text { made }\end{array}$ \\
\hline
\end{tabular}




\begin{tabular}{|c|c|c|c|}
\hline \multicolumn{4}{|l|}{ Child Victims } \\
\hline $\begin{array}{l}\text { Where do we } \\
\text { look? }\end{array}$ & What do we look for? & $\begin{array}{l}\text { Who is likely to } \\
\text { be the first } \\
\text { point of } \\
\text { contact? }\end{array}$ & $\begin{array}{l}\text { How do we } \\
\text { ensure that we } \\
\text { are picking up } \\
\text { the signs? }\end{array}$ \\
\hline $\begin{array}{l}\text { Interviews } \\
\text { with } \\
\text { unaccom- } \\
\text { panied } \\
\text { asylum } \\
\text { seeking } \\
\text { children }\end{array}$ & $\begin{array}{l}\text { Has prepared a story similar } \\
\text { to those other children have } \\
\text { given } \\
\text { Mistrust of authority figure } \\
\text { Has mobile phone but no } \\
\text { money }\end{array}$ & $\begin{array}{l}\text { Children's } \\
\text { Services }\end{array}$ & $\begin{array}{l}\text { Social workers } \\
\text { trained in } \\
\text { identification of } \\
\text { trafficked children }\end{array}$ \\
\hline $\begin{array}{l}\text { On the } \\
\text { streets }\end{array}$ & $\begin{array}{l}\text { Children begging } \\
\text { Children committing petty } \\
\text { crime, e.g. pick pocketing } \\
\text { Underage street prostitution }\end{array}$ & $\begin{array}{l}\text { Crime and } \\
\text { Disorder } \\
\text { Reduction } \\
\text { Partnerships } \\
\text { Youth Offending } \\
\text { Teams }\end{array}$ & $\begin{array}{l}\text { CDRPs and } \\
\text { Youth Offending } \\
\text { teams build } \\
\text { awareness of } \\
\text { child trafficking }\end{array}$ \\
\hline
\end{tabular}

\begin{tabular}{|c|c|c|c|}
\hline \multicolumn{4}{|l|}{ Adult Victims } \\
\hline $\begin{array}{l}\text { Where do we } \\
\text { look? }\end{array}$ & What do we look for? & $\begin{array}{l}\text { Who is likely to } \\
\text { be the first point } \\
\text { of contact? }\end{array}$ & $\begin{array}{l}\text { How do we } \\
\text { ensure that we } \\
\text { are picking up } \\
\text { the signs? }\end{array}$ \\
\hline $\begin{array}{l}\text { Massage } \\
\text { parlours }\end{array}$ & $\begin{array}{l}\text { High security measures exist } \\
\text { in the work/living quarters } \\
\text { (e.g. opaque windows, board } \\
\text { up windows, bars, barbed } \\
\text { wire, security cameras, etc) } \\
\text { Women are not free to come } \\
\text { and go as they wish or to } \\
\text { take breaks } \\
\text { Women appear to be under } \\
18 \\
\text { Women show signs of } \\
\text { physical/sexual abuse, } \\
\text { physical restraint, } \\
\text { confinement or torture }\end{array}$ & $\begin{array}{l}\text { Licensing officers } \\
\text { Prostitution } \\
\text { outreach teams }\end{array}$ & $\begin{array}{l}\text { Training for } \\
\text { licensing officers } \\
\text { Prostitution } \\
\text { outreach strategy } \\
\text { includes } \\
\text { identification and } \\
\text { assistance of } \\
\text { trafficked victims }\end{array}$ \\
\hline
\end{tabular}




\begin{tabular}{|c|c|c|c|}
\hline \multicolumn{4}{|l|}{ Adult Victims } \\
\hline $\begin{array}{l}\text { Where do we } \\
\text { look? }\end{array}$ & What do we look for? & $\begin{array}{l}\text { Who is likely to } \\
\text { be the first point } \\
\text { of contact? }\end{array}$ & $\begin{array}{l}\text { How do we } \\
\text { ensure that we } \\
\text { are picking up } \\
\text { the signs? }\end{array}$ \\
\hline $\begin{array}{l}\text { On the } \\
\text { streets }\end{array}$ & $\begin{array}{l}\text { The woman appears } \\
\text { unhappy and fearful } \\
\text { Women show signs of } \\
\text { physical/sexual abuse, } \\
\text { physical restraint, } \\
\text { confinement or torture } \\
\text { Special services are offered, } \\
\text { included unprotected sex at a } \\
\text { low price } \\
\text { Woman only knows how to } \\
\text { say sex-related words in } \\
\text { English } \\
\text { Women appear to be } \\
\text { controlled closely by a pimp }\end{array}$ & $\begin{array}{l}\text { Prostitution } \\
\text { outreach teams } \\
\text { Gender equality } \\
\text { officers }\end{array}$ & $\begin{array}{l}\text { Prostitution } \\
\text { outreach strategy } \\
\text { includes } \\
\text { identification and } \\
\text { assistance of } \\
\text { trafficked victims }\end{array}$ \\
\hline $\begin{array}{l}\text { Shops, } \\
\text { restaurants } \\
\text { and factories }\end{array}$ & $\begin{array}{l}\text { Staff show signs of physical } \\
\text { abuse or restraint } \\
\text { Poor or non-existent safety } \\
\text { equipment } \\
\text { Workers do not have suitable } \\
\text { clothing for their work } \\
\text { Workers have no days off or } \\
\text { holiday time } \\
\text { Employer is holding their } \\
\text { identification documents }\end{array}$ & $\begin{array}{l}\text { Health and Safety } \\
\text { Inspectors } \\
\text { Environmental } \\
\text { Health Officers } \\
\text { Trading } \\
\text { Standards } \\
\text { Officers }\end{array}$ & $\begin{array}{l}\text { Health and safety } \\
\text { officers, } \\
\text { environmental } \\
\text { health officers } \\
\text { and trading } \\
\text { standards officers } \\
\text { are trained in } \\
\text { victim awareness }\end{array}$ \\
\hline $\begin{array}{l}\text { Private } \\
\text { homes }\end{array}$ & $\begin{array}{l}\text { Overcrowded conditions, with } \\
\text { many people sharing } 1 \text { room } \\
\text { Occupants do not know their } \\
\text { own address } \\
\text { Occupants are not allowed } \\
\text { outside the house unless } \\
\text { their 'employer' is with them } \\
\text { Minibuses pick up occupants } \\
\text { at unusual times }\end{array}$ & $\begin{array}{l}\text { Housing officers } \\
\text { Adult social } \\
\text { services } \\
\text { Migrant } \\
\text { integration teams }\end{array}$ & $\begin{array}{l}\text { Housing officers } \\
\text { trained in victim } \\
\text { awareness } \\
\text { Migrant } \\
\text { integration } \\
\text { strategy includes } \\
\text { awareness of } \\
\text { human trafficking } \\
\text { issues }\end{array}$ \\
\hline
\end{tabular}




\begin{tabular}{|l|l|l|l|}
\hline \multicolumn{2}{|l|}{ Adult Victims } \\
\hline $\begin{array}{l}\text { Where do we } \\
\text { look? }\end{array}$ & What do we look for? & $\begin{array}{l}\text { Who is likely to } \\
\text { be the first point } \\
\text { of contact? }\end{array}$ & $\begin{array}{l}\text { How do we } \\
\text { ensure that we } \\
\text { are picking up } \\
\text { the signs? }\end{array}$ \\
\hline $\begin{array}{l}\text { Local } \\
\text { Authority } \\
\text { Premises }\end{array}$ & $\begin{array}{l}\text { Workers on cleaning } \\
\text { contracts arrive in minibuses } \\
\text { and appear to be fearful } \\
\text { Workers on building contracts } \\
\text { arrive in minibuses and } \\
\text { appear to be controlled } \\
\text { Workers do not have their } \\
\text { own identification papers } \\
\text { Workers have no days off or } \\
\text { holiday time }\end{array}$ & All council staff & $\begin{array}{l}\text { Distribution of } \\
\text { Blue Blindfold/ } \\
\text { STOP THE } \\
\text { TRAFFIK } \\
\text { pamphlets on } \\
\text { victim } \\
\text { identification to all } \\
\text { council staff }\end{array}$ \\
\hline
\end{tabular}

Whilst each of these indicators alone is not sufficient to verify that a person has been trafficked, the presence of a number of indicators should raise suspicion and the member of staff concerned should follow internal procedures on trafficking. If the council believe that there are reasonable grounds to believe that the individual has been trafficked, they should notify the UK Human Trafficking Centre.

Sources: The information included here draws upon the UKHTC Blue Blindfold Campaign and the London LSCB Trafficking toolkit. 